\title{
Adenovirus-mediated delivery of interferon- $\gamma$ gene inhibits the growth of nasopharyngeal carcinoma
}

Ran-yi Liu ${ }^{1 \dagger}$, Ying-hui Zhu ${ }^{1 \dagger}$, Ling Zhou ${ }^{1}$, Peng Zhao ${ }^{1,2}$, Hong-li Li ${ }^{1,3}$, Lan-cai Zhu ${ }^{1}$, Hong-yu Han ${ }^{1}$, Huan-xin Lin ${ }^{1}$, Liang Kang ${ }^{4}$, Jiang-xue $\mathrm{Wu}^{1 *}$ and Wenlin Huang ${ }^{1,5,6^{*}}$

\begin{abstract}
Background: Interferon- $\gamma$ (IFN- $\gamma$ ) is regarded as a potent antitumor agent, but its clinical application is limited by its short half-life and significant side effects. In this paper, we tried to develop IFN- $\gamma$ gene therapy by a replication defective adenovirus encoding the human IFN- $\gamma$ (Ad-IFNy), and evaluate the antitumoral effects of Ad-IFNy on nasopharyngeal carcinoma (NPC) cell lines in vitro and in xenografts model.

Methods: The mRNA levels of human IFN- $\gamma$ in Ad-IFNy-infected NPC cells were detected by reverse transcription-polymerase chain reaction (RT-PCR), and IFN- $\gamma$ protein concentrations were measured by enzyme-linked immunosorbent assay (ELISA) in the culture supernatants of NPC cells and tumor tissues and bloods of nude mice treated with Ad-IFNy. The effects of Ad-IFNy on NPC cell proliferation was determined using MTT assay, cell cycle distribution was determined by flow cytometry analysis for DNA content, and cells apoptosis were analyzed by Annexin V-FITC/7-AAD binding assay and hoechst 33342/PI double staining. The anti-tumor effects and toxicity of Ad-IFNy were evaluated in BALB/C nude mice carrying NPC xenografts.

Results: The results demonstrated that Ad-IFNy efficiently expressed human IFN- $\gamma$ protein in NPC cell lines in vitro and in vivo. Ad-IFNy infection resulted in antiproliferative effects on NPC cells by inducing G1 phase arrest and cell apoptosis. Intratumoral administration of Ad-IFNy significantly inhibited the growth of CNE-2 and C666-1 cell xenografts in nude mice, while no significant toxicity was observed.
\end{abstract}

Conclusions: These findings indicate IFN- $\gamma$ gene therapy mediated by replication defective adenoviral vector is likely a promising approach in the treatment of nasopharyngeal carcinoma.

Keywords: Gene therapy, Interferon- $\gamma$, Nasopharyngeal carcinoma, Adenoviral vector

\section{Background}

Nasopharyngeal carcinoma (NPC) is a rare tumor arising from the epithelium of the nasopharynx. However, it has a high incidence rate in South China and Southeast Asia [1]. Radiation therapy is the main strategy for local control of NPC [2], but the 5-year survival for stage IV NPC is only $30 \%$. The poor survival is often associated with high incidences of local, regional and systemic recurrences.

\footnotetext{
* Correspondence: wujx@sysucc.org.cn; wl_huang@hotmail.com

${ }^{\dagger}$ Equal contributors

'State Key Laboratory of Oncology in South China, Sun Yat-sen University Cancer Center, 651 Dong-feng Road East, Guangzhou 510060, China ${ }^{5}$ Institute of Microbiology, Chinese Academy of Science, Beijing 100101, China

Full list of author information is available at the end of the article
}

Although concurrent chemoradiotherapy is developed as a standard treatment approach for advanced NPC, the outcome isn't still satisfactory [3]. Therefore, the development of multidisciplinary therapeutic approaches is crucial for improvement of survival in NPC patients.

Interferon- $\gamma$ (IFN- $\gamma)$, a multifunctional cytokine produced mainly by $\mathrm{T}$ helper cells, cytotoxic $\mathrm{T}$ cells and natural killer cells [4], exerts antiviral, antiproliferative, immunomodulatory and antiangiogenesis effects [5]. IFN- $\gamma$ inhibits the growth of numerous tumors [6-10] and has been tried to use in the clinical management of tumors [11-14]. However, the clinical application of recombinant IFN- $\gamma$ protein is hampered by its short half-life and significant side effects. IFN- $\gamma$ Gene therapy can continuously

\section{Biomed Central}


produce and release therapeutic protein in local focus to overcome the obstacle of recombinant IFN- $\gamma$ protein $[9,10,15,16]$.

In this study, we tried to develop IFN- $\gamma$ gene therapy by a replication defective adenovirus encoding the human IFN- $\gamma$ (Ad-IFN $\gamma$ ) on nasopharyngeal carcinoma (NPC), our results showed Ad-IFN $\gamma$ effectively expressed in NPC cells, significantly inhibited tumor cell proliferation and induced cell apoptosis in vitro, inhibited the growth of xenografts in nude mice.

\section{Methods}

\section{Materials}

Dulbecco's Modified Eagle Medium (DMEM), fetal bovine serum, propidium iodide (PI), and TRIzol ${ }^{\circledR}$ reagent were from Invitrogen (Carlsbad, CA, USA). Reverse Transcription System and GoTaq ${ }^{\circledR}$ DNA Polymerase were from Promega (Beijing) Biotech Co., Ltd (Beijing, China). Annexin V-FITC/ 7-AAD apoptosis detection kit was from Beckman Coulter, Inc. (Marseille, France), while Double Stain Apoptosis Detection Kit (Hoechst 33342/PI) from GenScript USA Inc. (Piscataway, NJ, USA). Rabbit anti-human Ki-67 polyclonal antibody was from NeoMarkers For Lab Vision Corporation (Fremont, CA, USA), and StreptavidinHorseradish Peroxidase kit from Beijing Zhongshan Golden Bridge Biotechnology Co. (Beijing, China). In Situ Cell Death Detection kit was purchased from Roche Applied Science (Mannheim, Germany). Human interferon- $\gamma$ ELISA kit was purchased from Boster (Wuhan, China), recombinant human interferon- $\gamma($ rhIFN- $\gamma$ ) protein was from Shanghai Clonbiotech. Co., Ltd (Shanghai China). (3(4,5-Dimethylthiazol-2-yl)-2,5-diphenyltetrazolium bromide (MTT) and all other reagents were of molecular biology grade and obtained from Sigma-Aldrich (Shanghai, China).

\section{Cell lines, recombinant adenoviruses and infection}

Human nasopharyngeal carcinoma (NPC) cell lines CNE-1, CNE-2 and C666-1 were maintained in DMEM containing $10 \%$ fetal bovine serum (FBS) at a humidified atmosphere with $5 \% \mathrm{CO}_{2}$ at $37^{\circ} \mathrm{C}$. Replication defective adenoviruses encoding human interferon- $\gamma$ (Ad-IFN $\gamma$ ) and $\beta$-galactosidase (Ad-LacZ), kindly provided by Guangzhou Doublle Bioproducts Co., Ltd., were stored at $-80^{\circ} \mathrm{C}$ for use.

For adenovirus infection, NPC cells were seeded and cultured for $24 \mathrm{~h}$, and then removed culture medium, washed with phosphate buffered saline (PBS) ( $\mathrm{pH} 7.4$ ), followed by infection with adenovirus in serum-free DMEM for $3 \mathrm{~h}$. After removal of residual virus by PBS washing, cells were cultured in normal medium for indicated time before the analyses of IFN- $\gamma$ expression, cell proliferation and apoptosis.
Reverse transcription-polymerase chain reaction (PCR)

Cells were harvested and total RNAs were extracted using TRIzol ${ }^{\circledR}$ reagent according to the manufacture's instruction. mRNAs were transcribed into cDNAs and PCR reactions were carried out using their specific primer pairs: IFN- $\gamma^{\prime}$ s sense, $5^{\prime}$ - TTCAGCTCTGCATCGTTTTG-3', antisense, $5^{\prime}$-TTACTGGGATGCTCTTCGAC-3' (amplicon 473 bp); $\beta$-actin's sense, $5^{\prime}$-CGTCTTCCCCTCCATCGTG-3', antisense, $5^{\prime}$ - TAGCACAGCCTGGATAGCAAC-3' (amplicon $334 \mathrm{bp}$ ). Amplification was done with an initial cycle of $95^{\circ} \mathrm{C}$ for $4 \mathrm{~min}$, followed by 30 cycles of $95^{\circ} \mathrm{C}$ for $30 \mathrm{~s}, 55^{\circ} \mathrm{C}$ for $50 \mathrm{~s}, 72^{\circ} \mathrm{C}$ for $30 \mathrm{~s}$, with a final extension at $72^{\circ} \mathrm{C}$ for $10 \mathrm{~min}$. PCR products were analyzed by ethidium bromide staining on $1.5 \%$ agarose gels.

\section{Enzyme-linked Immunosorbent Assay (ELISA)}

NPC cells were seeded into 6-well plate at a density of $1 \times 10^{5}$ cells/well for 24 hours and then infected with adenoviruses as described above. The culture supernatants were collected at different time points and IFN- $\gamma$ concentration was determined by ELISA according to the manufacture's instruction (Boster, Wuhan, China) (the sensitivity is $15.6 \mathrm{pg} / \mathrm{mL}$ ).

\section{Cell proliferation analysis}

The effect of Ad-IFNY on NPC cell proliferation was determined using MTT assay as previously described [17]. Briefly, cells were seeded in 96-well plates at a density of 2000 cells/well for 24 hours and then infected with adenoviruses as described above, followed by incubation for $72 \mathrm{~h}$. Viable cells were stained with MTT for 4 hours and followed by determination of $\mathrm{OD}_{570 \mathrm{~nm}}$ with a reference wavelength at $630 \mathrm{~nm}$.

\section{Cell cycle distribution and apoptosis analysis}

Cell cycle distribution was determined by flow cytometry analysis for DNA content. Briefly, cells were harvested by trypsinization and washed by PBS, and followed by fixed in cold $70 \%$ ethanol for 1 hour at $4^{\circ} \mathrm{C}$. Cell suspensions were washed twice in PBS, treated by ribonuclease and followed by PI staining. And then cells were performed flow cytometry analysis for DNA content and cell cycle distribution.

Cells apoptosis were analyzed by Annexin V-FITC/ 7-AAD binding assay and hoechst 33342/PI double staining. Both floating and adherent cells were harvested and washed by PBS, then followed by staining according to the manufacture's instruction. Cells stained with Annexin V-FITC/7-AAD were analyzed by flow cytometry, while those stained with hoechst 33342/PI were analyzed by fluorescence microscopy.

\section{Animal model and experimental design}

Female BALB/c nude mice (5-6 weeks old, 18-20 g) were obtained from Shanghai Slike Experimental Animals Co. 
Ltd. (License No. SCXK(hu)2003-0003), housed and fed under specific pathogen-free conditions (Certificate No. 26-2004C008) according to protocols approved by the Sun Yat-sen University Institutional Animal Care and Use Committee. All of the animal experiments were performed in accordance with Guidelines for the Welfare of Animals in Experimental Neoplasia. The pieces (about $1.5 \mathrm{~mm}$ in diameter) of CNE-2 or C666-1 tumors, which were maintained by serial subcutaneous transplantation in $\mathrm{BALB} / \mathrm{c}$ nude mice, were subcutaneously transplanted into the flanks of mice to construct xenograft model.

To test the expression of Ad-IFNY in vivo, mice were intratumorally injected with $2 \times 10^{9}$ pfu in $100 \mu \mathrm{L}$ of PBS when CNE- 2 xenografts reached an approximate diameter of $7 \mathrm{~mm}$. Tumor tissues and bloods were collected at different time. IFN $\gamma$ concentration in the samples was measured by ELISA.

To assess antitumor effects of Ad-IFNY in vivo, mice were randomly assigned into eight groups (7-8 mice per group) when xenografts reached 4-5 mm diameter. Mice were treated by weekly intratumoral injection of $100 \mu \mathrm{L}$ of PBS, $2 \times 10^{9}$ pfu (plaque-forming unit) of Ad-LacZ, $2 \times 10^{9}$ pfu, $1 \times 10^{9} \mathrm{pfu}, 5 \times 10^{8} \mathrm{pfu}$, or $1 \times 10^{8} \mathrm{pfu}$ of Ad-IFNY (in $100 \mu \mathrm{L}$ of PBS) per dose respectively; while mice in other two groups were treated by daily intratumoral injection of $100 \mu \mathrm{L}$ of normal saline or $1 \times 10^{6} \mathrm{IU} /(\mathrm{kg}$ body weight) of rhIFN- $\gamma$ protein per dose respectively. The treatment was performed for three consecutive weeks, every injection was distributed equally into each half (8-12 mm of diameter) or quadrants ( $>12 \mathrm{~mm}$ of diameter) of tumors. Body weight and tumor size were measured every 4-5 days, and tumor xenografts were weighed at the end point of experiments.

\section{Histological analysis}

Tumor tissue was fixed in buffered formalin and embedded in paraffin. Sections ( $5 \mu \mathrm{M}$ thick) were mounted on Poly-LLysine treated slides, standard H\&E staining was utilized for histopathological assay. Human Ki67 immunohistochemistry was performed for cell proliferation assay, while TUNEL labeling was done using a fluorescent in situ cell death detection kit for apoptosis analysis in tumor tissues.

\section{Statistical analysis}

All experiments were repeated at least three times. The data were analyzed with One-way ANOVA or $t$ test by using SPSS 10.0 for Windows software (SSPS Inc., Chicago, IL, USA). $\mathrm{P}<0.05$ was considered statistically significant.

\section{Results}

\section{Ad-IFN $\gamma$ efficiently expressed hIFN $\gamma$ in NPC cells}

To evaluate the capability of Ad-IFNy expressed transgenic product in nasopharyngeal carcinoma (NPC) cells, we firstly investigated IFN $\gamma$ mRNA levels in CNE-2 cells after Ad-IFN $\gamma$ infection at different multiplicities of infection
(MOIs) at different time. The results showed that Ad-IFNY efficiently transcribed human IFN $\gamma$ gene in CNE-2 cells at a dose-dependent manner (Figure 1A), hIFNY mRNA was detected as early as 8 hours after Ad-IFN $\gamma$ infection, the levels reached the top at 48 hours after infection, and then gradually decreased, while No IFN $\gamma$ mRNA was detected in Ad-LacZ-infected cells (Figure 1B).

We investigated IFNY expression at protein levels in CNE-1, CNE-2 or C666-1 infected by Ad-IFN $\gamma$, and found that IFNY protein concentration in the supernatants of NPC cells continuously increased within 72 hours post-infection (Figure 1C). The differences from IFN $\gamma$ mRNA which peaked at 48 hours may be due to the instability of the mRNA. No IFN $\gamma$ proteins were found in the supernatants of Ad-LacZ-infected NPC cells (data not shown).

\section{Ad-IFNY inhibited the proliferation of NPC cells in vitro}

We evaluated the effects of Ad-IFNY on the proliferation of nasopharyngeal carcinoma (NPC) cells by MTT assay after $72 \mathrm{~h}$ after Ad-IFNY infection. The anti-proliferative effects of Ad-IFNY on NPC cells were shown in Figure 2A. AdIFNY inhibited the proliferation of CNE-1, CNE-2 and C666-1 NPC cell lines from 1 to 100 MOIs at a dosedependent manner. No significant inhibition was observed on NPC cells after infection with 50 MOIs of Ad-LacZ.

To explore the mechanism involved in proliferation inhibition of Ad-IFN $\gamma$ on NPC cells, the cell cycle profiles were analyzed by flow cytometry for DNA contents on NPC cells after infection with 100 MOIs of adenoviruses for $72 \mathrm{~h}$. The results showed a significantly higher percentage at the G1 phase in the cells infected with Ad-IFNY than those in Ad-LacZ infected cells (CNE-2: $70.8 \% \pm 6.3 \%$ vs $56.1 \% \pm 5.9 \%, \mathrm{p}<0.05$; C666- 1 : $75.8 \% \pm 6.9 \%$ vs $62.0 \% \pm 4.8 \%, \mathrm{p}<0.05$ ) (Figure $2 \mathrm{~B}$ ). These indicated that Ad-IFNY possesses an effect of G1 phase arrest on NPC cells.

\section{Ad-IFN $\gamma$ induced the apoptosis of NPC cells in vitro}

To examine the fate of Ad-IFN $\gamma$-infected NPC cell lines, an Annexin V/7-AAD binding assay and Hoechst 33342/PI double staining were performed after treatment with 100 MOIs of adenoviruses for $72 \mathrm{~h}$. The results showed that there was an increased fraction of Annexin $\mathrm{V}^{+} / 7-\mathrm{AAD}^{-}$(early apoptosis) and Annexin $\mathrm{V}^{+} / 7-$ $\mathrm{AAD}^{+}$(late apoptosis) in Ad-IFN $\gamma$-infected NPC cells than those of Ad-LacZ-infected cells (CNE-2, 21.2\% vs $5.3 \%, \mathrm{p}<0.01$; C666-1, $16.3 \%$ vs $6.4 \%, \mathrm{p}<0.01$ ) (Figure $3 \mathrm{~A}$ ). In Hoechst 33342/PI double staining assay, there were higher percentages of bright blue cells (apoptosis) in NPC cells infected with Ad-IFN $\gamma$ than those with Ad-LacZ (CNE-2, 25.2\% vs 4.8\%, p<0.01; C666-1, $19.5 \%$ vs $3.0 \%$, $\mathrm{p}<0.01$ ) (Figure 3B). These data suggested that Ad-IFNY induced the apoptosis in NPC cells. 

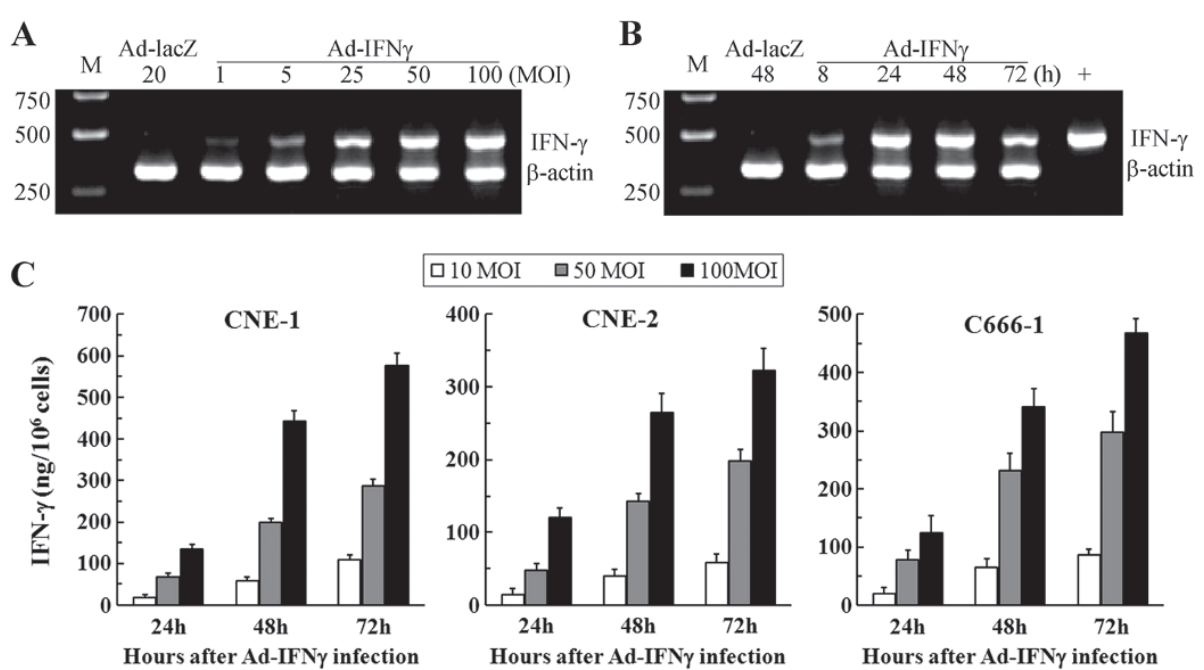

Figure 1 Ad-IFNy effectively expressed human IFN- $\gamma$ in NPC cells. (A) Dose-dependent IFN- $\gamma$ expression at mRNA level. After CNE-2 cells were infected with Ad-IFNy at different multiplicities of infection (MOIs) (20 MOls of Ad-LacZ as negative control) for 24 hours, human IFNy mRNA levels were detected by RT-PCR in CNE-2 cells (IFNy 473 bp; human $\beta$-actin as internal control, 334 bp). (B) Time course of IFN-y expression at mRNA level. IFNy mRNA levels were detected by RT-PCR in CNE-2 cells infected with 50 MOls of Ad-IFNy for 8, 24,48 or 72 hours, CNE-2 cells infected with $50 \mathrm{MOls}$ of Ad-LacZ for 48 hours were used as negative control. (C) IFN-y expression at protein levels in NPC cells. CNE-1 (left), CNE-2 (middle) or C666-1 (right) cells were infected with Ad-IFNy at indicated MOls, the culture supernatants were then sampled at different time points, and IFN- $\gamma$ concentrations in the supernatants were detected by ELISA (Boster, Wuhan, China). IFN- $\gamma$ expression efficiency was displayed as $\mathrm{ng} / 10^{6}$ cells.

\section{Ad-IFNy efficiently expressed human IFN $\gamma$ in NPC xenografts in nude mice}

To evaluate the dynamic expression of AdIFNy in vivo, we measured the levels of hIFN $\gamma$ in tumor and blood samples collected from nude mice carrying CNE-2 NPC xenografts on days 1, 3, 5 and 7 after intratumoral injection with Ad-IFN $\gamma$. The results showed that Ad-IFN $\gamma$ efficiently expressed hIFN $\gamma$ in NPC xenografts, the concentration of hIFN $\gamma$ in tumor tissue was $(136.5 \pm 25.5) \mathrm{pg} /(\mathrm{mg}$ tissue $)$ at 24 hours post-injection of AdIFN $\gamma$, reached the peak of (265.8 \pm 26.2$) \mathrm{pg} /(\mathrm{mg}$ tissue) at 72 hours, and then decreased gradually to $(61.1 \pm 8.3) \mathrm{pg} /(\mathrm{mg}$ tissue $)$ at day 7 (Figure 4A). hIFNy were also detected in blood. As same as in tumor tissue, the concentration of hIFNy reached the peak of $(64.9 \pm 15.9) \mathrm{pg} / \mathrm{mL}$ after 3 days post-injection, and then decreased gradually to $(18.9 \pm 7.3) \mathrm{pg} / \mathrm{mL}$ at day 7 .

\section{Ad-IFN $\gamma$ inhibited the growth of human NPC xenografts}

Administration of Ad-IFNy resulted in significant growth suppression of NPC xenografts compared to the control groups. As shown in Figure $5 \mathrm{~A}$ and $5 \mathrm{~B}$, tumor growth in the Ad-IFN $\gamma$-treated groups was significantly slower than that in Ad-LacZ (vector control) group or PBS (medium control) group. The inhibition effects showed a clear dose-dependent manner. At the end of experiment, the tumor weights in Ad-IFNy groups were significantly lighter than those in Ad-LacZ or PBS group (Figure $5 \mathrm{C}$ and $5 \mathrm{D}$ ), $1 \times 10^{8}, 5 \times 10^{8}, 1 \times 10^{9}$ and $2 \times 10^{9} \mathrm{pfu} /$ dose of Ad-IFN $\gamma$ treatment respectively produced $24.1 \%$, $43.2 \%, 64.8 \%$, and $73.5 \%$ of growth inhibition for CNE-2 xenografts (Figure 5C), 42.6\%, 54.3\%, 71.3\% and $81.7 \%$ of growth inhibition for C666-1 xenografts (Figure 5D). However, $2 \times 10^{9} \mathrm{pfu} /$ dose of Ad-LacZ barely inhibited tumor growth. The efficacy of daily intratumoral injection of $1 \times 10^{6} \mathrm{IU} /(\mathrm{kg}$ body weight)/day of $\mathrm{rhIFN \gamma}$ was likely similar with that of the administration of $5 \times 10^{8} \mathrm{pfu} /$ dose/ week of Ad-IFNy. There were no significant differences on body weights between Ad-IFN $\gamma$-treated and Ad-LacZ or PBS-treated mice ( $>0.05$, data not shown), which indicated low general toxicity on Ad-IFNy treatment.

Representative tumors harvested from each group were processed for histological analyses. Pathologic analysis (via $H \& E$ staining) found that there were large areas of necrosis in the tumor tissue treated with Ad-IFN $\gamma$, while few necrotic areas were observed in the Ad-LacZtreated and PBS-treated tumors (data not shown). Cell proliferation was estimated by the immunohistochemical assessment of the nuclear antigen $\mathrm{Ki}-67$. The results showed that Ki-67 was significantly lower in tumor tissue treated with Ad-IFNy than those in Ad-LacZ group and PBS group. For apoptosis analysis, TUNEL positive ratios were significantly higher in Ad-IFNy groups than those in Ad-LacZ group and PBS group. The representative pictures for Ki-67 and TUNEL staining in PBS group, Ad-LacZ group, and $1 \times 10^{9}$ pfu Ad-IFN $\gamma$ group were shown in Figure 6. 

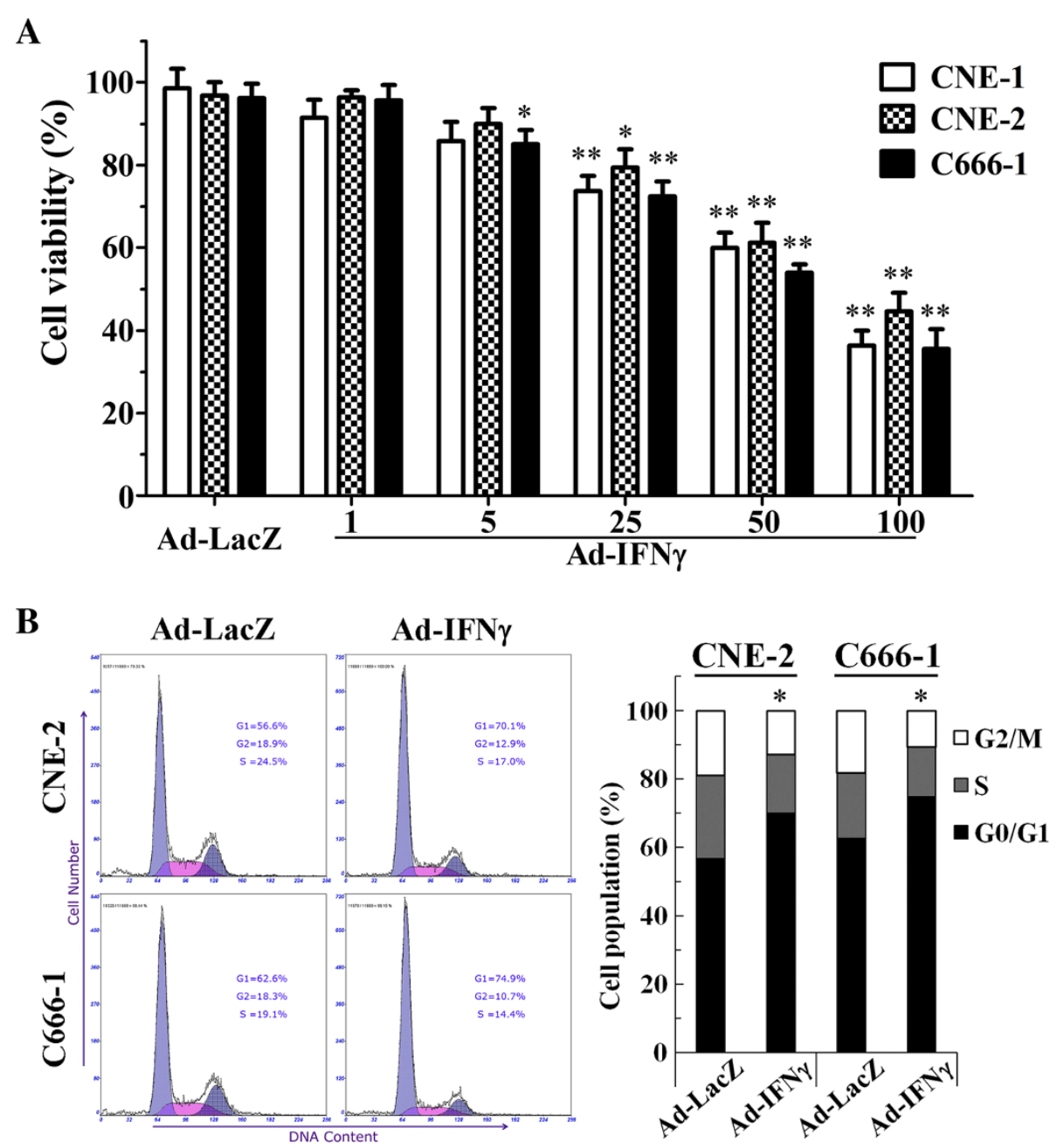

Figure 2 Ad-IFNY inhibited the proliferation of NPC cells by inducing G1 phase arrest in vitro. (A) Cell viability assay. CNE-2 or C666-1 cells were infected with Ad-IFNy at different MOls for 72 h, followed by MTT assay for cell viability. (B) Cell cycle distribution. CNE-2 or C666-1 cells were infected with Ad-IFNy at 50 MOls for 48 h, followed by flow cytometry analysis for DNA content and cell cycle distribution as described in "Materials and methods". ${ }^{*} p<0.05,{ }^{* *} p<0.01$ while compared with corresponding cells infected with Ad-LacZ, N=3.

\section{Discussion}

Interferon- $\gamma$ (IFN- $\gamma$ ), as a multifunctional cytokine, exerts diverse biological functions related to host defense and immune regulation, such as inflammation, innate and acquired immunity, cell cycle and apoptosis [5]. IFN- $\gamma$ plays a critical role in promoting protective host responses to tumors, which proposed mechanisms include, (a) anti-proliferative and pro-apoptotic actions, (b) anti-angiogenesis in tumors, and (c) promoting both the innate and adoptive immune responses against tumors $[20,21]$.

Although IFN- $\gamma$ has been investigated as a potential therapeutics for various types of tumors [6-13], the attempts to improve antitumor efficacy by increasing the dose or by repetitive continuous administration resulted in higher toxicity and low efficacy [22]. Considerable experimental data from our group and other investigators demonstrated that intratumoral IFN- $\gamma$ gene transfer to achieve long-term, continuous locoregional exposure of IFN- $\gamma$ is likely an appropriate approach for improving efficacy and reducing toxicity of IFN- $\gamma[9,10,15,16,23,24]$. In this study, we reported that adenovirus-mediated IFN- $\gamma$ gene transfer (Ad-IFN $\gamma$ ) inhibited tumor growth of human nasopharyngeal carcinoma (NPC) cells (Figure 2 and Figure 5). Here the anti-NPC activity of IFN- $\gamma$ included not only direct anti-proliferative and pro-apoptotic actions, also indirect mechanisms, such as immunomodulation and antiangiogenesis.

Ad-IFN $\gamma$ efficiently expressed human IFN- $\gamma$ in nasopharyngeal carcinoma cells in vitro and in vivo (Figure 1 and Figure 3), and exhibited strong antiproliferative effects (Figure 2A and Figure 6). According to previous reports, the antiproliferative mechanisms of IFN- $\gamma$ seem to be cell type specific [9,25-29], either induction of cell 

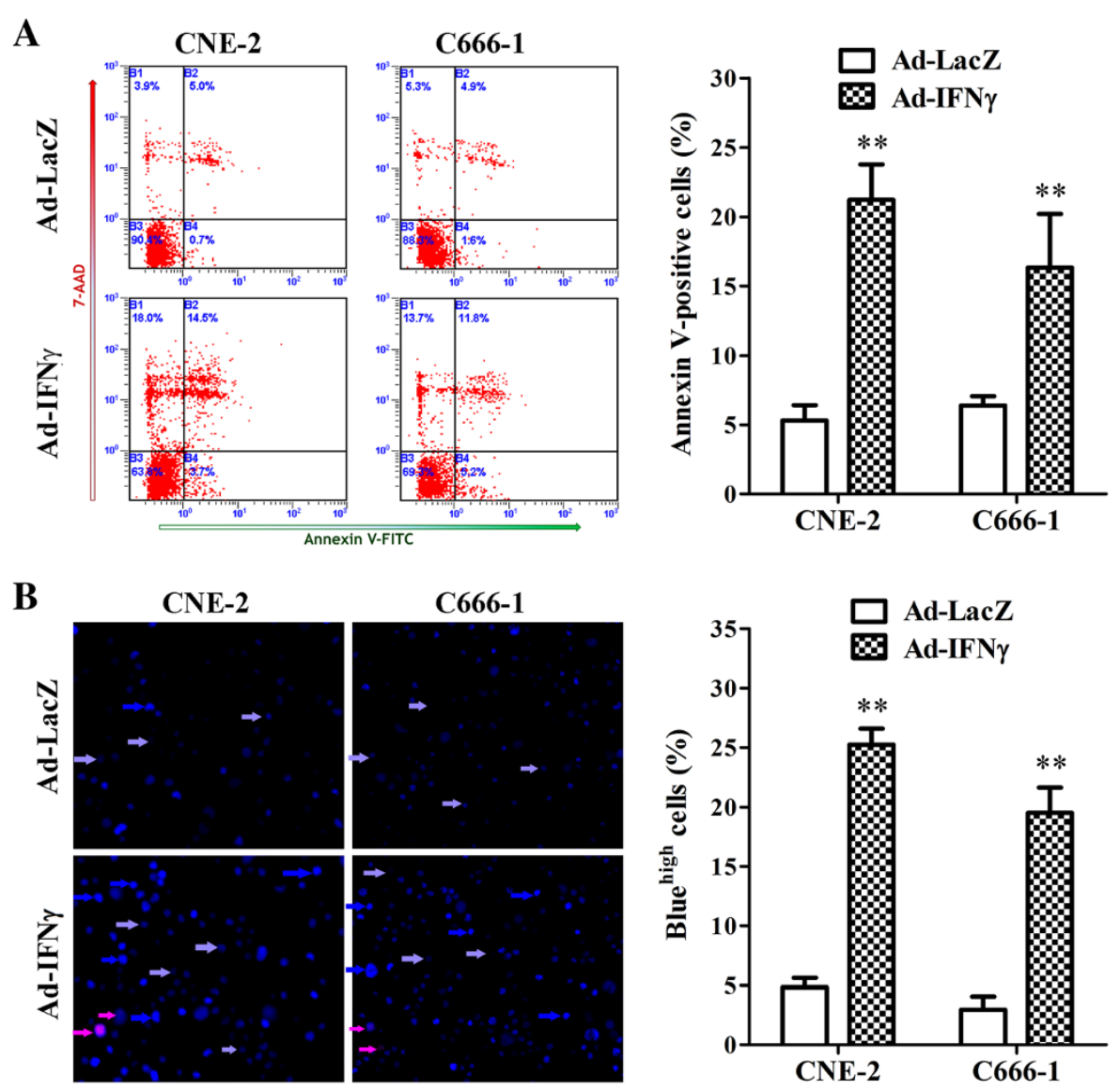

Figure 3 Ad-IFNY induced apoptosis in NPC cells. Both floating and adherent NPC cells were harvested after infection with $50 \mathrm{MOI}$ of Ad-IFNY or Ad-LacZ for $72 \mathrm{hr}$, washed with ice-cold PBS and followed by apoptosis analysis. (A) Annexin V-FITC/7-AAD binding assay by flow cytometry. $5 \times 10^{5}$ of collected cells were incubated in the dark for 15 minutes with $100 \mu \mathrm{L}$ of $1 \times$ Binding Buffer containing $10 \mu \mathrm{L}$ of Annexin V-FITC and $20 \mu \mathrm{L}$ of 7-ADD Viability Dye (Beckman-Coulter, Inc. Marseille, France) on ice. Samples were diluted with $400 \mu \mathrm{L}$ of 1xBinding Buffer and immediately analyzed by a Coulter Epics Altra flow cytometer (Beckman-Coulter). Left, Diagrams in a representative experiment. Annexin $V^{+} / 7-$ $A A D^{-}$indicates early apoptotic cells, and Annexin $V^{+} / 7-A A D^{+}$indicates late apoptotic cells. Right, Statistical analysis of Annexin $V$-positive cells (apoptotic cells) generated from three independent experiments. (B) Hoechst 33342/PI double staining. Collected cells were adjusted to the density of $1 \times 10^{6}$ cells $/ \mathrm{mL}$ in PBS with $1 \% \mathrm{FBS}$ and stained with $5 \mu \mathrm{M}$ of Hoechst 33342 at $37^{\circ} \mathrm{C}$ for $10 \mathrm{~min}$. And then cells were stained with $1 \mu \mathrm{M}$ of PI for $10 \mathrm{~min}$ at room temperature after washing with PBS to remove Hoechst dye. The stained cells were mounted onto a polylysinecoated slide and examined under a fluorescent microscope. A total of 300 400 nuclei from 5 8 randomly chosen fields were examined. High blue fluorescent indicates apoptotic cells (bright blue arrow), low blue indicates live cells (azury arrow), while red represents dead cells (pink arrow). Apoptosis was expressed as a percentage of the total number of nuclei examined. Left, Representative pictures from one experiment. Right, Statistical analysis of apoptotic cells from three independent experiments. ${ }^{* *} p<0.01$, compared with Ad-LacZ-treated cells.

cycle arrest or apoptosis. Here we found that both G1 phase arrest and apoptosis contributed to AdIFN $\gamma$-mediated growth suppression in NPC cell lines (Figure 2B, Figure 3 and Figure 6), consistent with the report that the antiproliferative effects of minicircleIFNY on NPC cell lines could be attributed to G1 arrest and apoptosis [9]. The JAK/STAT pathway may be responsible for most biological effects mediated by IFN- $\gamma$ $[20,30]$, which regulates different cell cycle-associated proteins that control the G1-S checkpoint [25], or induce cell apoptosis through up-regulating the expression of various apoptosis-related proteins in different cell types [31-33].
Although antiproliferation and apoptosis induction were main effects of Ad-IFNy-mediated anti-NPC in this study, antiangiogenesis may contribute also to growth inhibition of NPC xenografts in nude mice. Because the microvessel densities (MVDs) were found to be decreased in the xenografts treated with Ad-IFNY compared with those treated with Ad-LacZ or PBS in our study (data not shown). Previous studies reveal that IP-10, an inhibitor of angiogenesis, could be induced by IFN- $\gamma$ in endothelial cells and exert potent antiangiogenesis activity by inhibiting endothelial cell differentiation, motility and tube formation $[34,35]$. However, due to highly species specificity, human unlikely exerts direct effects on murine vascular 

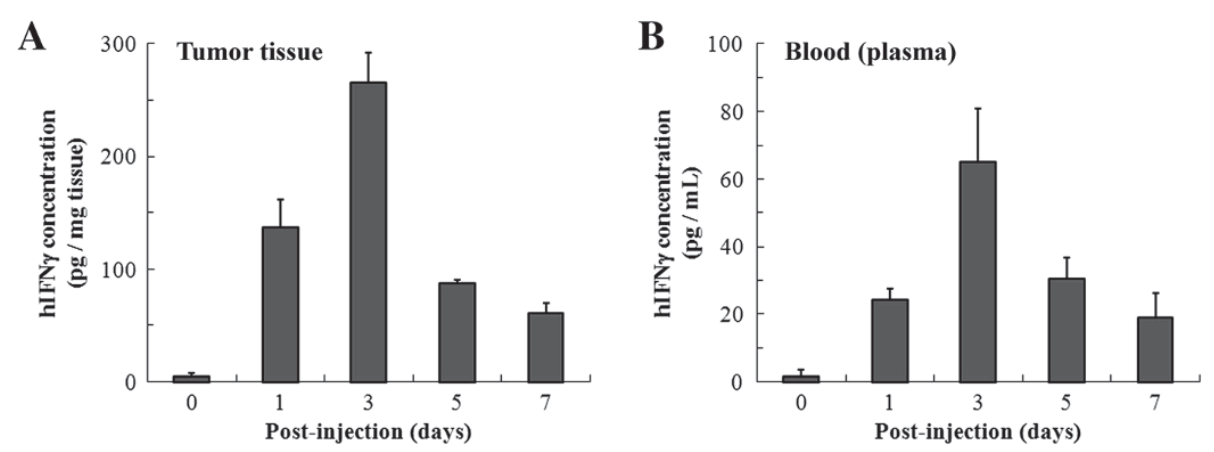

Figure 4 Ad-IFN $\gamma$ effectively expressed human IFN- $\gamma$ in NPC xenografts in nude mice. Mice were intratumorally injected with $2 \times 10^{9}$ pfu of Ad-IFNY, and then collected tumor tissues (A) and bloods (B) 1 day, 3, 5 and 7 days after Ad-IFNy injection (mice before injection marked "day 0" as negative control, 3-4 mice per time point). Tumor tissues were made into homogenates in cold PBS, and then human IFNy concentrations in the tissue homogenates and blood plasmas were measured by using human interferon- $\gamma$ ELISA kit (Boster, Wuhan, China).

system, but likely acts on tumor cells to indirectly regulate angiogenesis. It was reported that IFN- $\gamma$ acted as antiangiogenic cytokine by inhibiting the expression of angiogenic factors, such as VEGF or perlecan, in renal cell carcinoma [36], stromal fibroblasts [37], human cornea [38], and WiDr/HT29 colon carcinoma cells[39], or by inducing the expression of anti-angiogenic factor monokine induced by interferon-gamma (MIG, or CXCL9) in nonsmall cell lung carcinom [40]. Here we would like to make a hypothesis that IFN- $\gamma$ may exert antiangiogenic effect in nude mice carrying NPC xenografts by regulating the expression of some angiogenic or antiangiogenic factors in
NPC cells. This hypothesis, of course, needs to be tested and verified.

Human and murine IFN- $\gamma$ display low level of sequence homology (only 40\%) at protein level, which explains why the human and murine proteins display a strict species specificity in their ability to bind to and activate human and murine cells [41]. So human IFN- $\gamma$ has less activity in the nude mouse host, though nude mice display potent macrophage and NK cell activity [42-44] and remain some basal T-cell function [45]. Direct immunomodulation on mouse immune system by human IFN- $\gamma$ unlikely contributes to its antitumor effects. However, we cannot exclude
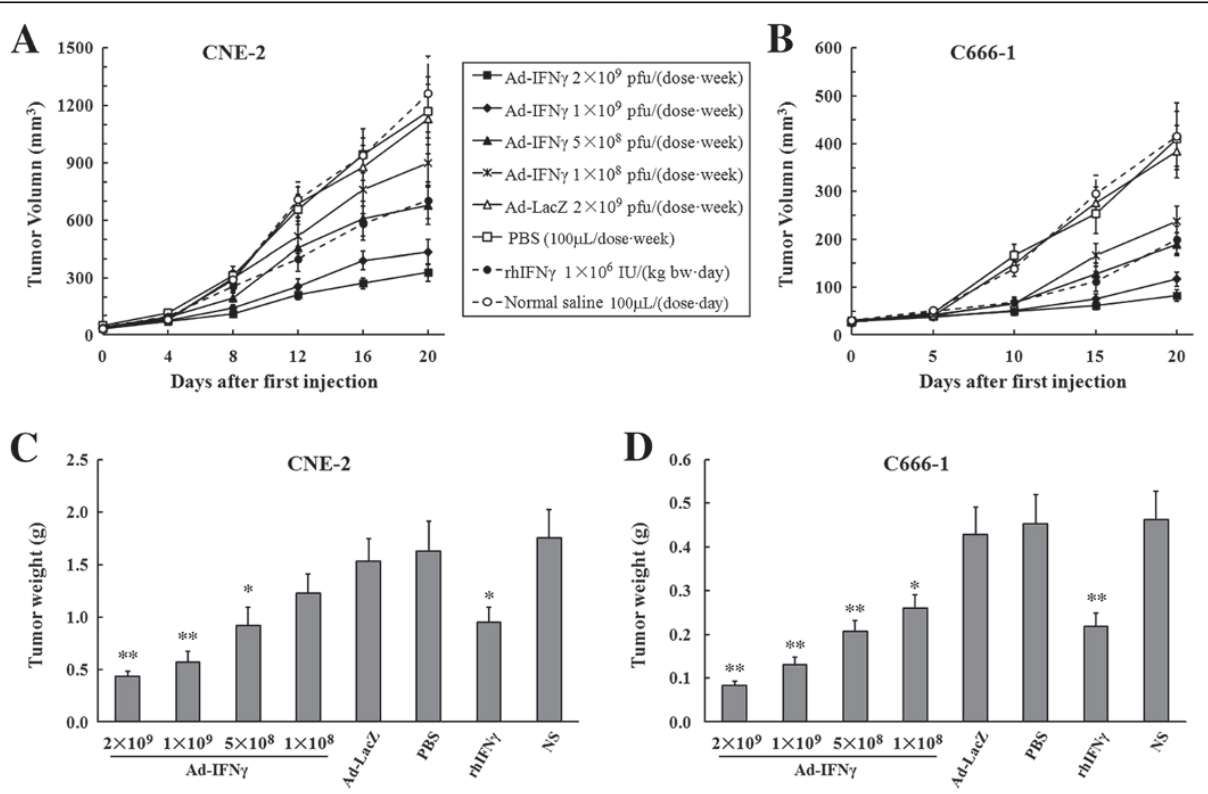

Figure 5 Ad-IFNY inhibited the growth of human NPC xenografts. When CNE-2 or C666-1 xenografts reached 4-5 mm diameter, mice were randomly assigned (7 8 mice per group) and treated by weekly intratumoral injection of $100 \mu \mathrm{L}$ of PBS, Ad-LacZ or Ad-IFNy (in $100 \mu \mathrm{L}$ of PBS) or by daily intratumoral injection of $100 \mu \mathrm{L}$ of normal saline (NS) or rhlFN- $\gamma$ protein (in $100 \mu \mathrm{L}$ of NS), respectively. (A, B) Tumor growth curves. Tumor size was measured every 4 days for CNE-2 xenografts (A) or 5 days for C666-1 (B), and the volume (V) was calculated according to the following formula: $V=0.52 \times$ length $\times$ width $^{2}[18,19]$. (C, D) Tumor weights. After 3 weeks of treatment, mice with CNE-2 (C) or C666-1 (D) xenografts were sacrificed and tumor tissues were resected followed by weighing. ( ${ }^{*} p<0.05,{ }^{* *} p<0.01$ compared with corresponding media). 


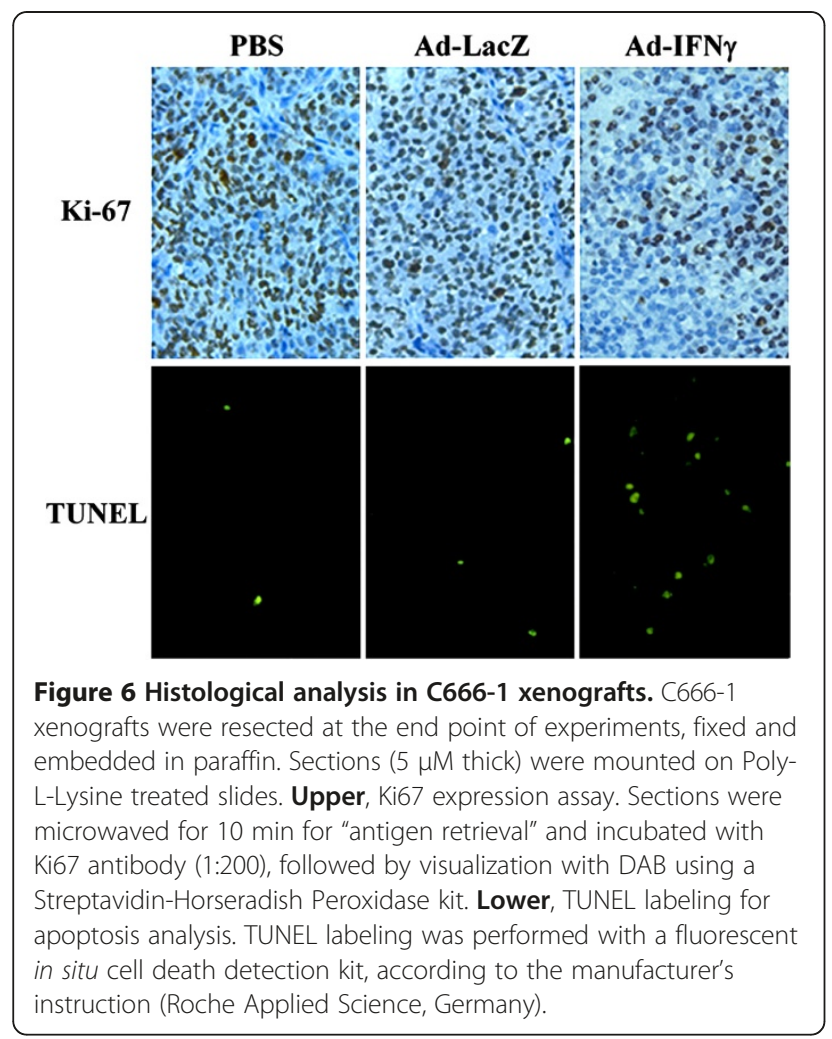

the possibility that other indirect effects are involved in Ad-IFN $\gamma$-mediated antitumor immune response. Firstly, human IFN- $\gamma$ could modify the expression of MHC and costimulatory molecules or cytokines, chemokines on human NPC cells [21,46], which may activate the residual immune system of nude mice. Secondly, adenoviral vector and heterogenous IFN- $\gamma$ expression likely induce a nonspecific immune response directed by NK and/or microphage cells in nude mice [47].

Taken together, Ad-IFN $\gamma$ displayed efficient anti-NPC activities by inhibiting tumor cell proliferation and induced cell apoptosis in this study. Additional indirect effects on antiangiogenesis and immunomodulatory may also be involved in this antitumor activity. So IFN- $\gamma$ gene therapy by a replication defective adenovirus encoding the human IFN- $\gamma(\mathrm{Ad}-\mathrm{IFN} \gamma)$ is likely a potential novel therapeutics on comprehensive therapy of nasopharyngeal carcinoma.

Nevertheless, recent reports have shown that the immune response activated by IFN- $\gamma$ plays a dual role in cancer: It can not only suppress tumor growth by destroying cancer cells or inhibiting their outgrowth but also promote tumor progression either by selecting for tumor cells that are more fit to survive in an immunocompetent host or by establishing conditions within the tumor microenvironment that facilitate tumor outgrowth [48]. IFN- $\gamma$ treatment is a double-edged sword whose anti- and protumorigenic activities are dependent on the cellular, microenvironmental, and/or molecular context [30]. Thereby, more investigations should be carried out to clarify the influences of cellular, microenvironmental, immunological and molecular events on the anti-NPC effects of Ad-IFNY before its clinical application.

\section{Conclusions}

The results of the present study indicate that Ad-IFNY likely performs potent anti-nasopharyngeal carcinoma effects by inhibiting cell proliferation, inducing G1 phase arrest and cell apoptosis. These findings have implications for the use of IFN- $\gamma$ gene therapy mediated by replication defective adenoviral vector as a promising approach in the treatment of nasopharyngeal carcinoma.

\section{Abbreviations}

IFN-ү: Interferon-gamma; rhIFNy: Recombinant human interferon-gamma; Ad-IFNY: A replication defective adenovirus encoding the human IFN- $\gamma$; Ad-LacZ: A replication defective adenovirus encoding $\beta$-galactosidase; NPC: Nasopharyngeal carcinoma; RT-PCR: Reverse transcription-polymerase chain reaction; ELISA: Enzyme-linked immunosorbent assay; MTT: (3-(4,5-Dimethylthiazol-2-yl)-2,5-diphenyltetrazolium bromide; PI: Propidium iodide; DMEM: Dulbecco's Modified Eagle Medium; PBS: Phosphate buffered saline; FBS: Fetal bovine serum; H\&E: Hematoxylin and eosin; MOls: Multiplicities of infection; TUNEL: TdT-mediated dUTP-biotin nick end labeling;

MVD: Microvessel density; MIG: Monokine induced by interferon-gamma; NK cell: Natural killer cell.

\section{Competing interests}

The authors declare that they have no competing interests.

\section{Authors' contributions}

$\mathrm{RL}$ carried out the cell proliferation and apoptosis analysis, collected and analyzed all of results, and designed and drafted the article. YZ LCZ and $\mathrm{HL}$ performed the animal experiments. LZ evaluated the expression of IFN- $\gamma$ by RT-PCR and ELISA. PZ carried out immunohistochemical assay. HL and LK made animal model. $\mathrm{HH}$ performed and validated the statistical data. JW and $\mathrm{WH}$ conceived and coordinated the work, and helped in drafting the manuscript. All authors have read and approved the final manuscript.

\section{Acknowledgements}

This study was supported by the National High Technology Research and Development Program of China (project 863, No. 2012AA020403; 2012AA02A204), the National Natural Science Foundation of China (No. 81071822), Guangdong Province Natural Science Fund (No. 9451008901002636) and Guangdong Innovative Research Team Program (No. 2009010058). We also thank Guangzhou Doublle Bio-product Inc. (Guangzhou, China) for their kindly providing recombinant adenoviruses Ad-IFNY and Ad-LacZ.

\section{Author details}

${ }^{1}$ State Key Laboratory of Oncology in South China, Sun Yat-sen University Cancer Center, 651 Dong-feng Road East, Guangzhou 510060, China. ${ }^{2}$ Department of Medical Oncology, The First Affiliated Hospital, College of Medicine, Zhejiang University, Hangzhou 310003, China. ${ }^{3}$ Department of Gastrointestinal Oncology, Tianjin Medical University Cancer Institute and Hospital, Tianjin 300060, China. ${ }^{4}$ Department of Colorectal Surgery, the Sixth Affliated Hospital, Sun Yat-sen University, Guangzhou 510655, China. ${ }^{5}$ Institute of Microbiology, Chinese Academy of Science, Beijing 100101, China. ${ }^{6}$ Guangdong Provincial Key Laboratory of Tumor-targeted Drug, Guangzhou Doublle Bioproducts Co., Ltd., Guangzhou 510663, China.

Received: 25 October 2012 Accepted: 17 December 2012

Published: 28 December 2012 


\section{References}

1. Adham M, Kurniawan AN, Muhtadi Al, Roezin A, Hermani B, Gondhowiardjo S, Tan IB, Middeldorp JM: Nasopharyngeal carcinoma in Indonesia: epidemiology, incidence, signs, and symptoms at presentation. Chin J Cancer 2012, 31:185-196.

2. Xiao WW, Han F, Lu TX, Chen CY, Huang Y, Zhao C: Treatment outcomes after radiotherapy alone for patients with early-stage nasopharyngeal carcinoma. Int J Radiat Oncol Biol Phys 2009, 74:1070-1076.

3. Pan XB, Zhu XD: Role of chemotherapy in stage llb nasopharyngeal carcinoma. Chin J Cancer 2012, 31:573-578.

4. Boehm U, Klamp T, Groot M, Howard JC: Cellular responses to interferongamma. Annu Rev Immunol 1997, 15:749-795.

5. Schroder K, Hertzog PJ, Ravasi T, Hume DA: Interferon-gamma: an overview of signals, mechanisms and functions. J Leukoc Biol 2004, 75:163-189.

6. Kominsky SL, Hobeika AC, Lake FA, Torres BA, Johnson HM: Downregulation of neu/HER-2 by interferon-gamma in prostate cancer cells. Cancer Res 2000, 60:3904-3908.

7. Sasagawa T, Hlaing M, Akaike T: Synergistic induction of apoptosis in murine hepatoma Hepa1-6 cells by IFN-gamma and TNF-alpha. Biochem Biophys Res Commun 2000, 272:674-680.

8. Detjen KM, Farwig K, Welzel M, Wiedenmann B, Rosewicz S: Interferon gamma inhibits growth of human pancreatic carcinoma cells via caspase-1 dependent induction of apoptosis. Gut 2001, 49:251-262.

9. Wu J, Xiao X, Zhao P, Xue G, Zhu Y, Zhu X, Zheng L, Zeng Y, Huang W: Minicircle-IFNgamma induces antiproliferative and antitumoral effects in human nasopharyngeal carcinoma. Clin Cancer Res 2006, 12:4702-4713.

10. Zhao P, Zhu YH, Wu JX, Liu RY, Zhu XY, Xiao X, Li HL, Huang BJ, Xie FJ, Chen JM, et al: Adenovirus-mediated delivery of human IFNgamma gene inhibits prostate cancer growth. Life Sci 2007, 81:695-701.

11. Kane A, Yang I: Interferon-gamma in brain tumor immunotherapy. Neurosurg Clin N Am 2010, 21:77-86.

12. Windbichler GH, Hausmaninger H, Stummvoll W, Graf AH, Kainz C, Lahodny J, Denison U, Muller-Holzner E, Marth C: Interferon-gamma in the first-line therapy of ovarian cancer: a randomized phase III trial. Br J Cancer 2000, 82:1138-1144.

13. Hastie C: Interferon gamma, a possible therapeutic approach for latestage prostate cancer? Anticancer Res 2008, 28:2843-2849.

14. Miller CH, Maher SG, Young HA: Clinical use of Interferon-gamma. Ann N Y Acad Sci 2009, 1182:69-79.

15. Dummer R, Eichmuller S, Gellrich S, Assaf C, Dreno B, Schiller M, Dereure O, Baudard M, Bagot M, Khammari A, et al: Phase II clinical trial of intratumoral application of TG1042 (adenovirus-interferon-gamma) in patients with advanced cutaneous T-cell lymphomas and multilesional cutaneous B-cell lymphomas. Mol Ther 2010, 18:1244-1247.

16. Wu J, Xiao X, Jia H, Chen J, Zhu Y, Zhao P, Lin H, Huang W: Dynamic distribution and expression in vivo of the human interferon gamma gene delivered by adenoviral vector. BMC Cancer 2009, 9:55.

17. Liu RY, Dong Z, Liu J, Yin JY, Zhou L, Wu X, Yang Y, Mo W, Huang W, Khoo SK, et al: Role of elF3a in regulating cisplatin sensitivity and in translational control of nucleotide excision repair of nasopharyngeal carcinoma. Oncogene 2011, 30:4814-4823.

18. O'Reilly MS, Boehm T, Shing Y, Fukai N, Vasios G, Lane WS, Flynn E, Birkhead $\mathrm{JR}$, Olsen BR, Folkman J: Endostatin: an endogenous inhibitor of angiogenesis and tumor growth. Cell 1997, 88:277-285.

19. Li L, Liu RY, Huang JL, Liu QC, Li Y, Wu PH, Zeng YX, Huang W: Adenovirusmediated intra-tumoral delivery of the human endostatin gene inhibits tumor growth in nasopharyngeal carcinoma. Int J Cancer 2006, 118:2064-2071.

20. Ikeda H, Old LJ, Schreiber RD: The roles of IFN gamma in protection against tumor development and cancer immunoediting. Cytokine Growth Factor Rev 2002, 13:95-109.

21. Dunn GP, Ikeda H, Bruce AT, Koebel C, Uppaluri R, Bui J, Chan R, Diamond $M$, White JM, Sheehan KC, Schreiber RD: Interferon-gamma and cancer immunoediting. Immunol Res 2005, 32:231-245.

22. Curnis F, Gasparri A, Sacchi A, Cattaneo A, Magni F, Corti A: Targeted delivery of IFNgamma to tumor vessels uncouples antitumor from counterregulatory mechanisms. Cancer Res 2005, 65:2906-2913.

23. Gattacceca F, Pilatte Y, Billard C, Monnet I, Moritz S, Le Carrou J, Eloit M, Jaurand MC: Ad-IFN gamma induces antiproliferative and antitumoral responses in malignant mesothelioma. Clin Cancer Res 2002, 8:3298-3304

24. Dummer R, Hassel JC, Fellenberg F, Eichmuller S, Maier T, Slos P, Acres B, Bleuzen $\mathrm{P}$, Bataille V, Squiban $\mathrm{P}$, et al: Adenovirus-mediated intralesional interferon-gamma gene transfer induces tumor regressions in cutaneous lymphomas. Blood 2004, 104:1631-1638.

25. Sangfelt O, Erickson S, Grander D: Mechanisms of interferon-induced cell cycle arrest. Front Biosci 2000, 5:D479-D487.

26. Chawla-Sarkar M, Lindner DJ, Liu YF, Williams BR, Sen GC, Silverman RH, Borden EC: Apoptosis and interferons: role of interferon-stimulated genes as mediators of apoptosis. Apoptosis 2003, 8:237-249.

27. Gollob JA, Sciambi CJ, Huang Z, Dressman HK: Gene expression changes and signaling events associated with the direct antimelanoma effect of IFN-gamma. Cancer Res 2005, 65:8869-8877.

28. Wall L, Burke F, Barton C, Smyth J, Balkwill F: IFN-gamma induces apoptosis in ovarian cancer cells in vivo and in vitro. Clin Cancer Res 2003, 9:2487-2496.

29. Dunn GP, Sheehan KC, Old $\sqcup$, Schreiber RD: IFN unresponsiveness in LNCaP cells due to the lack of JAK1 gene expression. Cancer Res 2005, 65:3447-3453.

30. Zaidi MR, Merlino G: The two faces of interferon-gamma in cancer. Clin Cancer Res 2011, 17:6118-6124.

31. Ruiz-Ruiz C, de Almodovar Ruiz C, Rodriguez A, Ortiz-Ferron G, Redondo JM, Lopez-Rivas A: The up-regulation of human caspase-8 by interferon-gamma in breast tumor cells requires the induction and action of the transcription factor interferon regulatory factor-1. J Biol Chem 2004, 279:19712-19720.

32. Miura Y, Tsujioka T, Nishimura Y, Sakaguchi H, Maeda M, Hayashi H, Dong M, Hyodoh F, Yata K, Wada H, et al: TRAIL expression up-regulated by interferon-gamma via phosphorylation of STAT1 induces myeloma cell death. Anticancer Res 2006, 26:4115-4124.

33. Barton C, Davies D, Balkwill F, Burke F: Involvement of both intrinsic and extrinsic pathways in IFN-gamma-induced apoptosis that are enhanced with cisplatin. Eur J Cancer 2005, 41:1474-1486.

34. Bodnar RJ, Yates CC, Rodgers ME, Du X, Wells A: IP-10 induces dissociation of newly formed blood vessels. J Cell Sci 2009, 122:2064-2077.

35. Bodnar RJ, Yates CC, Wells A: IP-10 blocks vascular endothelial growth factor-induced endothelial cell motility and tube formation via inhibition of calpain. Circ Res 2006, 98:617-625.

36. Sasamura H, Takahashi A, Miyao N, Yanase M, Masumori N, Kitamura H, Itoh N, Tsukamoto T: Inhibitory effect on expression of angiogenic factors by antiangiogenic agents in renal cell carcinoma. Br J Cancer 2002, 86:768-773.

37. Lu Y, Yang W, Qin C, Zhang L, Deng J, Liu S, Qin Z: Responsiveness of stromal fibroblasts to IFN-gamma blocks tumor growth via angiostasis. $\mathrm{J}$ Immunol 2009, 183:6413-6421.

38. Kommineni VK, Nagineni CN, William A, Detrick B, Hooks JJ: IFN-gamma acts as anti-angiogenic cytokine in the human cornea by regulating the expression of VEGF-A and sVEGF-R1. Biochem Biophys Res Commun 2008, 374:479-484

39. Sharma B, lozzo RV: Transcriptional silencing of perlecan gene expression by interferon-gamma. J Biol Chem 1998, 273:4642-4646.

40. Addison $\mathrm{CL}$, Arenberg DA, Morris SB, Xue YY, Burdick MD, Mulligan MS, lannettoni MD, Strieter RM: The CXC chemokine, monokine induced by interferon-gamma, inhibits non-small cell lung carcinoma tumor growth and metastasis. Hum Gene Ther 2000, 11:247-261.

41. Farrar MA, Schreiber RD: The molecular cell biology of interferon-gamma and its receptor. Annu Rev Immunol 1993, 11:571-611.

42. Zhang F, Lu W, Dong Z: Tumor-infiltrating macrophages are involved in suppressing growth and metastasis of human prostate cancer cells by INF-beta gene therapy in nude mice. Clin Cancer Res 2002, 8:2942-2951.

43. Nielsen LL: NK cells mediate the anti-tumor effects of E1-deleted, type 5 adenovirus in a human tumor xenograft model. Oncol Rep 2000, 7:151-155.

44. Sarkar D, Su ZZ, Vozhilla N, Park ES, Randolph A, Valerie K, Fisher PB: Targeted virus replication plus immunotherapy eradicates primary and distant pancreatic tumors in nude mice. Cancer Res 2005, 65:9056-9063.

45. Ikehara S, Pahwa RN, Fernandes G, Hansen CT, Good RA: Functional T cells in athymic nude mice. Proc Natl Acad Sci U S A 1984, 81:886-888.

46. Seliger B, Ruiz-Cabello F, Garrido F: IFN inducibility of major histocompatibility antigens in tumors. Adv Cancer Res 2008, 101:249-276.

47. Hu X, Chakravarty SD, Ivashkiv LB: Regulation of interferon and Toll-like receptor signaling during macrophage activation by opposing feedforward and feedback inhibition mechanisms. Immunol Rev 2008, 226:41-56.

48. Schreiber RD, Old $\mathrm{L}$, Smyth MJ: Cancer immunoediting: integrating immunity's roles in cancer suppression and promotion. Science 2011, 331:1565-1570.

doi:10.1186/1479-5876-10-256

Cite this article as: Liu et al:: Adenovirus-mediated delivery of interferon- $\gamma$ gene inhibits the growth of nasopharyngeal carcinoma. Journal of Translational Medicine 2012 10:256. 